\title{
EFFECT OF BACITRACIN ON ERYTHROID DIFFERENTIATION OF MEL CELLS
}

\author{
M. FORESTI ${ }^{1}$ and L. MIGLIORE ${ }^{2}$ \\ ${ }^{1}$ Dipt. Genetica, Biologia generale e molecolare, Università Federico II, Via \\ Mezzocannone, 8 - 80134 Napoli, and ${ }^{2}$ II Università degli Studi, Vle Beneduce \\ 81100 Casserta, Italy \\ Bacitracin, an antibiotic widely utilized in clinical and veterinary use, was tested \\ on murine erythroleukemia (MEL) cells. Tests were performed to evaluate the \\ capacity of the drug to interfere with erythroid differentiation. Cells were exposed \\ to a single treatment in $S$ phase at sublethal doses of bacitracin. Two responses \\ were found depending on the drug concentration. At higher concentrations \\ $(25 \mu \mathrm{g} / \mathrm{ml}$ and $250 \mathrm{ng} / \mathrm{ml})$ a reduction in number of differentiating cells was \\ observed but the kinetics of the process remained unchanged. At lower concentra- \\ tions (from $2.5 \mathrm{ng} / \mathrm{ml}$ to $2.5 \mathrm{fg} / \mathrm{ml}$ ) a dramatic alteration of the dynamic of differen- \\ tiation was found. These two responses are related to different activities of the DNA \\ repair mechanisms. Higher doses of bacitracin stimulate repair while lower \\ concentrations are not able to activate repair, as demonstrated by tests with \\ hydroxyurea. The bacitracin-induced damage can be considered a stable genetic \\ and/or epigenetic alteration, as demonstrated by the high frequency of mutant \\ clones isolated from low-dose treated cells. The suitability of MEL cells system in \\ evaluating genotoxicity of drugs for veterinary use is underlined.
}

\section{INTRODUCTION}

Bacitracin is a very well known and widely utilized antibiotic both in human therapy and in zootechnical farming. Generally considered of not very high toxicity (Goodman and Gilman, 1990), it showed a marked toxicity in vivo on macroinvertebrates as both acute and low-dose toxicity and teratogenic effect (Macrì et al., 1990; Migliore et al., 1991, 1994; Dojmi di Delupis et al., 1992).

To clarify the reasons for this discrepancy, bacitracin has been tested on a mammalian cell system by studying effects caused on expected differentiation in murine erythroleukemia (MEL) Friend cells (Friend et al., 1971). It has been previously reported that the ability of MEL cells to undergo erythroid differentiation can be permanently blocked by exposing the cells for a few hours at a sublethal dose of any of the several chemical mutagens (Foresti et al, 1990a,b), or UV irradiation (Foresti et al., 1992). However, it was shown that the period of sensitivity to mutagens corresponds

1. Address all correspondence to: L. Migliore, Università tor Vergata, Dipt Biologia, via Della Ricerca Scientifica, 00173 Roma, Italy

2. Key words: bacitracin; erythroid differentiation; murine erythroleukemia cells.

3. Abbreviations: MEL, murine erythroleukemia; HU, hydroxyurea. 
to the start of the $\mathrm{S}$ phase in MEL cell cultures parasynchronized in G1/S by induction with DMSO (Foresti et al., 1986) or synchronized in G1/S by thymidine and hydroxyurea blocks (Foresti et al., 1990a; Foresti et al., 1992). A strict correlation has been observed between the ability of a tested compound to damage the DNA and the inhibition of erythroid differentiation in MEL cells, as many chemicals that do not interact with DNA are without effect (Foresti et al., 1990a,b). The inhibition of differentiation, or of any other cellular function tested, such as G6PD or 6PGD or HPRT, caused by mutagenic agents is the result of a genetic damage, as a very high frequency (30-50\%) of cellular mutant clones can easily be isolated from the treated cultures (Foresti et al., 1990a,b, 1992). Studies on DNA repair activity during the cell cycle of MEL cells indicate that the DNA repair in the early $S$ phase is less efficient than in the remaining periods of the cell cycle (Foresti et al., 1990a; Foresti et al., 1992). The fixation of a mutation into the cellular genome is the result of several causes, all acting at the same time: (1) ability of the tested compound to damage DNA; (2) efficiency of DNA repair; (3) the period of the cell cycle when the cells are treated.

The aim of the present work is to evaluate the actual toxicity of bacitracin by studying its ability to interfere with the erythroid differentiation in erythroleukemia Friend (MEL) cells and the applicability of this cell system for the evaluation of the effects of drugs utilized in veterinary medicine.

\section{MATERIALS AND METHODS}

Mouse erythroleukemia cells (MEL), clone DS19 (Friend et al., 1971), were cultivated in Dulbecco's Modified Eagle medium supplemented with $7.5 \%$ fetal calf serum and $550 \mathrm{U} / \mathrm{ml}$ penicillin and $75 \mathrm{U} / \mathrm{ml}$ streptomycin. The cultures were kept in a humidified atmosphere of $10 \% \mathrm{CO}_{2}$ at $37^{\circ} \mathrm{C}$. Cell number and viability were assessed by Trypan blue exclusion in a hemocytometer.

MEL cells $\left(1 \times 10^{5}\right.$ cells $\left./ \mathrm{ml}\right)$ were induced to erythroid differentiation by addition of $2 \%$ DMSO to the culture medium, and the accumulation of hemoglobin was monitored by the benzidine staining (Orkin et al., 1975) at the indicated times. At least 200 cells were counted for each point in duplicate experiments. Bacitracin - and its zinc complex - is a polypeptide that, in solution, is rapidly inactivated (in a few hours) by salts of many of the heavy metals and by temperature (Martindale, 1989); for this reason the cell cultures were not washed. Zinc bacitracin (Apothekernes Lab., Oslo, Norway) $68.9 \mathrm{IU} / \mathrm{mg}$ was used. Serial dilutions of bacitracin from $25 \mu \mathrm{g} / \mathrm{ml}$ to $2.5 \mathrm{fg} / \mathrm{ml}$ were freshly prepared in distilled water and sterilized by Millipore filtration $(0.22 \mu \mathrm{m})$.

Evaluation of the effect of the drug on differentiation was performed following the protocol described by Foresti et al. (1986). Bacitracin was added to the culture medium at the 19th hour from the start of the induction ( $\mathrm{S}$ phase) and the effects both on cell viability and proliferation and on erythroid differentiation were determined. A zinc control was performed at $17.5 \mu \mathrm{M} \mathrm{ZnCl}_{2}$ (same molar concentration of Zn-bacitracin at the highest dose tested) and did not alter any of the mentioned cellular parameters. The inhibition of DNA repair was obtained by addition of $1 \mathrm{mM}$ hydroxyurea (HU) to the culture medium with bacitracin for $2 \mathrm{hr}$. Cells were allowed to differentiate and the percentage of benzidine-positive cells $\left(\% \mathrm{~B}^{+}\right)$was measured at the indicated 
day. Individual cell clones were obtained from the $250 \mathrm{pg} / \mathrm{ml}$ bacitracin-treated cells by plating the treated population in $0.4 \%$ agar in nonselective conditions (Foresti et al., 1993).

Data were analyzed by covariance analysis, $F$-test and $t$-test, taking into account all the replicates. Mean, standard errors (SE), medians and standard deviations (SD) are also reported.

\section{RESULTS}

The proliferating capacity of MEL cells after one treatment of bacitracin added to the cells (at the 19th hour from the start of induction, during the $S$ phase) is shown in Figure 1. Addition of bacitracin at all concentrations tested does not affect the viability and the proliferating rates of the treated cells.

The differentiation rates of MEL cells after the above-mentioned unique treatment of bacitracin is shown in Figure 2 (concentrations $25 \mu \mathrm{g} / \mathrm{ml}$ and $250 \mathrm{ng} / \mathrm{ml}$ ) and in Figure 3 (concentrations ranging from $2.5 \mathrm{ng} / \mathrm{ml}$ to $2.5 \mathrm{fg} / \mathrm{ml}$ ). The differentiating activity, measured as percentage of benzidine-positive $\left(\mathrm{B}^{+}\right)$cells is reported as trend. Figure 2 shows that, at the higher concentrations tested, there is a difference in the elevation but not in the slope between control and treated lines, indicating that the differentiating activity is reduced in the treated cell cultures but that the kinetics of differentiation is not altered. This is confirmed by the statistical analysis (Table 1): the high values of variance confirm that there is a positive correlation between time and number of differentiated cells and the

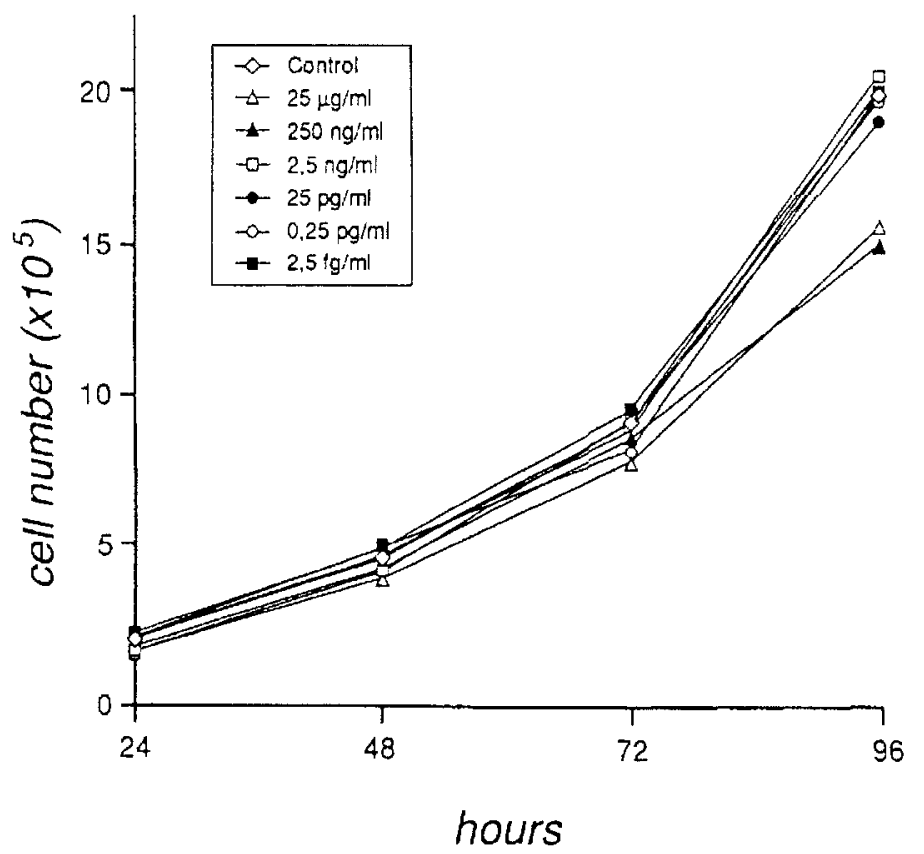

FIGURE 1. Proliferating activity of MEL cells in the presence of bacitracin, added at the 19th hour after induction; time is measured from the start of induction (addition of DMSO) and cell number is per ml of culture. 


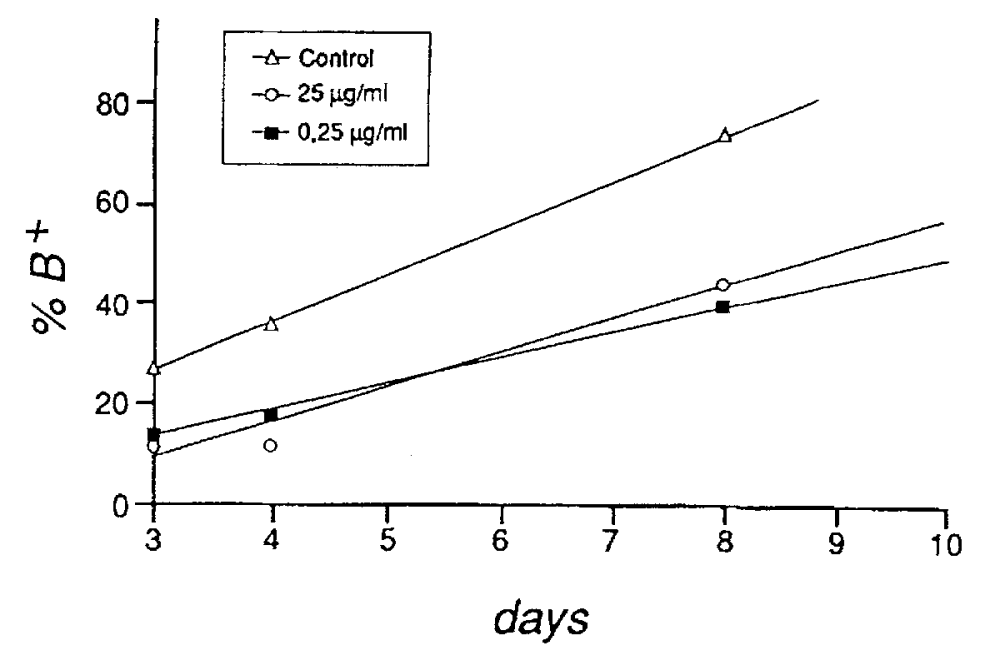

FIGURE 2. Differentiation rates (percentage of benzidine-positive cells, $\% \mathrm{~B}^{+}$, reported as trend) in the presence of higher doses $(25 \mu \mathrm{g} / \mathrm{ml}$ and $250 \mathrm{ng} / \mathrm{ml})$ of bacitracin added at the 19 th hour after the start of induction.

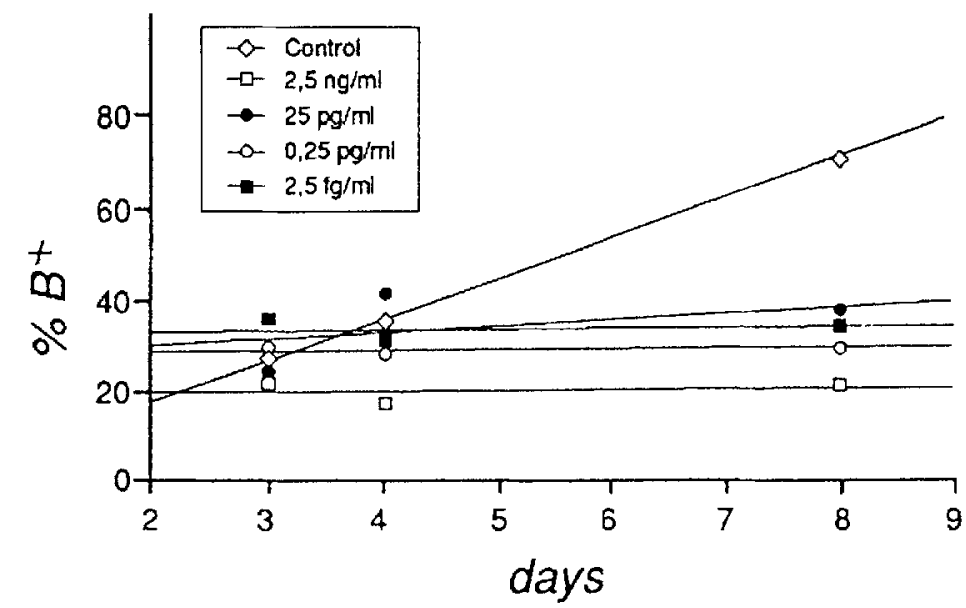

FIGURE 3. Differentiation rates (percentage of benzidine-positive cells, $\% \mathrm{~B}^{+}$, reported as trend) in the presence of lower doses (from $2.5 \mathrm{ng} / \mathrm{ml}$ to $2.5 \mathrm{fg} / \mathrm{ml}$ ) of bacitracin added at the 19th hour after the start of induction.

high values of covariance demonstrate that the processes of differentiation in control and treated cells have the same trend even if a quantitative difference is found. There is also a quantitative difference in the effect of the two concentrations tested. In contrast, Figure 3 shows a marked difference in the slope between control and treated lines, indicating that the lower concentrations of bacitracin (from $2.5 \mathrm{ng} / \mathrm{ml}$ to $2.5 \mathrm{fg} / \mathrm{ml}$ ) alter the kinetics of differentiation. In fact, the percentage of differentiation in the treated cells remains quite constant with time, while that of the control increases. These data are also confirmed by the statistical analysis (Table 1). The low values of variance indicate that the positive correlations between time and number of differentiated cells are no longer found 
TABLE 1. Analysis of the covariance of the various experimental samples. The variance of each sample is reported in bold

\begin{tabular}{lrrrrrrr}
\hline & Control & $25 \mu \mathrm{g} / \mathrm{ml}$ & $250 \mathrm{ng} / \mathrm{ml}$ & $2.5 \mathrm{ng} / \mathrm{ml}$ & $25 \mathrm{pg} / \mathrm{ml}$ & $0.25 \mathrm{pg} / \mathrm{ml}$ & $2.5 \mathrm{fg} / \mathrm{ml}$ \\
\hline Control & $\mathbf{3 8 4 . 2 2}$ & & & & & & \\
$25 \mu \mathrm{g} / \mathrm{ml}$ & 279.22 & $\mathbf{2 0 6 . 8 9}$ & & & & & \\
$250 \mathrm{ng} / \mathrm{ml}$ & 209.00 & 153.00 & $\mathbf{1 1 4 . 0 0}$ & & & & \\
$2.5 \mathrm{ng} / \mathrm{ml}$ & 12.89 & 9.86 & 8.00 & $\mathbf{3 . 5 6}$ & & & \\
$25 \mathrm{pg} / \mathrm{ml}$ & 34.78 & 18.44 & 17.00 & -4.89 & $\mathbf{1 4 . 8 9}$ & & \\
$0.25 \mathrm{pg} / \mathrm{ml}$ & 12.33 & 10.00 & 7.00 & 1.33 & -0.67 & $\mathbf{0 . 6 7}$ & \\
$2.5 \mathrm{fg} / \mathrm{ml}$ & $\mathbf{7 9 . 3 3}$ & 60.67 & 44.00 & 5.33 & 2.00 & 3.33 & $\mathbf{1 8 . 6 7}$ \\
\hline
\end{tabular}

TABLE 2. Effect of $1 \mathrm{mM}$ HU on the induction of bacitracin-treated cells

\begin{tabular}{|c|c|c|c|c|c|}
\hline & \multicolumn{2}{|c|}{ Induction } & \multicolumn{3}{|c|}{ Comparison } \\
\hline & $\begin{array}{l}\text { Mean } \\
\left(\% \mathrm{~B}^{+}\right)\end{array}$ & Variance & df & $F$ & $p$ \\
\hline Control & 25.2 & 0.09 & & & \\
\hline $25 \mathrm{ng} / \mathrm{ml}$ & 25.6 & 0.08 & & & \\
\hline $\begin{array}{l}\text { vs. } \\
25 \mathrm{ng} / \mathrm{ml}+\mathrm{HU}\end{array}$ & 10.5 & 8.82 & $1 ; 4$ & 110.25 & $<0.001$ \\
\hline $250 \mathrm{pg} / \mathrm{ml}$ & 7.2 & 9.68 & & & \\
\hline $\begin{array}{l}\text { vs. } \\
250 \mathrm{ng} / \mathrm{ml}+\mathrm{HU}\end{array}$ & 12.5 & 3.38 & $1 ; 4$ & 2.86 & ns \\
\hline $\begin{array}{l}25 \mathrm{ng} / \mathrm{ml}+\mathrm{HU} \\
\text { vs. } \\
250 \mathrm{pg} / \mathrm{ml}+\mathrm{HU}\end{array}$ & 10.5 & 8.82 & $1 ; 4$ & 2.61 & ns \\
\hline
\end{tabular}

ns, not significant

TABLE 3. Induction capability of clones isolated from control and bacitracin-treated cells

\begin{tabular}{|c|c|c|c|c|c|c|c|}
\hline & \multicolumn{5}{|c|}{ Induction } & \multicolumn{2}{|c|}{ Comparison } \\
\hline & $N$ & $\begin{array}{l}\text { Mean } \\
\left(\% \mathrm{~B}^{+}\right)\end{array}$ & $\mathrm{SE}$ & Median & SD & $t$ & $p$ \\
\hline Control & 5 & 54.60 & 10.08 & 50.00 & 17.43 & 5.76 & $<0.001$ \\
\hline $250 \mathrm{pg} / \mathrm{ml}$ & 19 & 15.61 & 4.36 & 8.15 & 18.50 & & \\
\hline
\end{tabular}


and the low or negative values of covariance demonstrated that the processes of differentiation in control and treated cells have independent trends.

To explore more extensively the unexpected dramatic effect of lower doses of bacitracin on erythropoiesis, the possible involvement of DNA repair mechanisms was investigated. Hydroxyurea, an inhibitor of DNA repair (Cress and Gerner, 1977), was added to two treated cultures at concentration (1mM) not interfering with MEL cell differentiation (Foresti et al., 1993). Concentrations of $25 \mathrm{ng} / \mathrm{ml}$ and $250 \mathrm{pg} / \mathrm{ml}$ bacitracin were chosen as representative of the two main effects reported in Figures 2 and 3. In Table 2 the effects of the addiction of HU on differentiation of treated cell culture (measured at day 3) are reported: $25 \mathrm{ng} / \mathrm{ml}$ bacitracin caused induction comparable to control. When HU was added, the percentage of induced cells dropped to 10.5 . The difference is statistically significant. In contrast, $250 \mathrm{pg} / \mathrm{ml}$ bacitracin caused $7.2 \%$ induction, lower than for $25 \mathrm{ng} / \mathrm{ml}$ bacitracin-treated and control cells. When HU was added, the percentage of induced cells did not differ statistically. Induction in $25 \mathrm{ng} / \mathrm{ml}$ and $250 \mathrm{pg} / \mathrm{ml}$ plus HU treated cells did not display statistically significant difference.

In addition, 19 cellular clones were isolated from $250 \mathrm{pg} / \mathrm{ml}$ bacitracin-treated cultures and 5 from control culture. Both groups were tested for induction. In Table 3 the differences in induction (at day 4) are reported. Control clones show a mean induction of $54.6 \%$, with a median of $50 \%$; treated cells show a mean induction of $15.61 \%$, with a median of $8.15 \%$. The difference, evaluated by $t$-test, is highly significant. Mutant clones from $25 \mathrm{ng} / \mathrm{ml}$ bacitracin-treated cells are not generated, as the damage was repaired and cells differentiated.

\section{DISCUSSION}

Bacitracin is very effective in damaging the normal dynamics of the MEL cell system. At all the concentrations tested, bacitracin caused an inhibition of the erythroid differentiation, but, as regard the kinetics of differentiation (Figures 2 and 3), two main responses can be found. At higher doses $(25 \mu \mathrm{g} / \mathrm{ml}$ and $250 \mathrm{ng} / \mathrm{ml})$, the kinetics of the process remain unchanged, and the few cells able to differentiate accumulate hemoglobin to the same extent as control cells. The lower doses (from $2.5 \mathrm{ng} / \mathrm{ml}$ to $2.5 \mathrm{fg} / \mathrm{ml}$ ) dramatically alter the kinetics of differentiation: the percentage of cells accumulating hemoglobin remains constant with time in treated batches, while it regularly increases in controls.

Bacitracin causes genetic and/or epigenetic alterations in MEL cells, as demonstrated by DNA repair and isolation of mutant cell clones. In fact, the addition of hydroxyurea (as inhibitor of DNA repair) to bacitracin high-dose treated cell culture causes an inhibition of differentiation. Bacitracin low-dose treated cell culture both with and without hydroxyurea shows no significantly different levels of inhibition. Furthermore, the levels of inhibition of the high-dose treated cells plus hydroxyurea and low-dose treated with or without hydroxyurea are not significantly different. This implies that high doses of bacitracin induce a variety of damage on DNA such as to induce repair and consequently the cell population shows qualitatively normal dynamics of 
differentiation. On the other hand, low doses appear unable to activate repair, so the majority of cells do not repair damage and remain much impaired in erythropoiesis, as shown by the completely different kinetics of differentiation. In conclusion, the "paradox" of higher damage at lower doses does not depend on different capacity of bacitracin to alter DNA but on different levels of repair activation. This is demonstrated by the same level of inhibition observed in the presence of hydroxyurea at high and low doses. These considerations are further supported by the ease of isolation of mutant clones altered in erythropoiesis from bacitracin low-dose treated cells, in comparison to the absence of mutant clones from high-dose treated cells.

The effects of bacitracin on erythroid differentiation are similar to those induced in MEL cells by mutagens such as mitomicin C, 1-nitropyrene, 9-aminoacridine, cyclophosphamide and many others (Foresti et al., 1986, 1990a,b) in a similar range of concentrations or by UV irradiation (Foresti et al., 1992). Furthermore, Quinlan and Gutteridge $(1989,1991)$ reported that bacitracin causes DNA-base damage by chemical reactions leading to the formation of reactive oxygen species. In fact, bacitracin and its zinc complex are able to reduce copper and iron salts with the formation of hydrogen peroxide; this results in damage to the bacitracin molecule and the release of oxidizing radicals that attack molecules such as deoxyribose and DNA. Furthermore, the mutagenic and toxic effects of hydrogen peroxide on DNA are well documented (Ames et al., 1982; Mello-Filho et al., 1984). The cascade reaction can account for the serious damage at very low concentrations such as $2.5 \mathrm{fg} / \mathrm{ml}$.

The capacity of bacitracin to interfere deeply with cellular differentiative processes has also been reported in Daphnia magna Straus and Artemia salina (L.), in which, apart from a dose-response death rate induction, behavioral and teratogenetic effects have also been recorded (Macrì et al., 1990; Migliore et al., 1991, 1994; Dojmi di Delupis et al., 1992).

Furthermore, this cell system appears interesting for the evaluation of the sublethal toxicity of drugs involved in veterinary medicine. Toxicologic studies on these drugs are performed according to EEC guidelines (Directive 70/524 "Feed additives" and 81/852 "Veterinary drugs") with the classical in vitro and in vivo methods that suppose the availability of a certain quantity of drug. Our results stress the importance of alternative in vitro methodologies, such as the MEL cell system, that give results at very low concentrations and thus might be used to test drug residues in animal tissue and/or the toxicology of their metabolites. This kind of test has economic relevance in that it is less expensive than the in vivo tests.

In conclusion, bacitracin - an antibiotic widely utilized in clinical and veterinary therapy and considered of low toxicity - deeply damages the MEL cell system; furthermore, the high sensitivity of this system indicates its suitability in detecting the toxicity of drugs.

\section{ACKNOWLEDGMENTS}

The work was performed in collaboration with the Istituto Superiore di Sanità, Laboratorio Medicina 
Veterinaria, Roma. The authors are grateful to Professors G. Geraci and A. Macrì for the criticism in all the phases of the work. Work supported by $60 \%$ and $40 \%$ MURST grants (Progetto "Fondamenti scientifici della conservazione della natura", Responsabile Prof. O. Rossi).

\section{REFERENCES}

AMES, B.N., MALLSTEIN, M.C., and CATHCART, R. (1982). "Lipid peroxidation and oxidative damage to DNA." Lipid Peroxidases in Biology and Medicine (K. Yagi, ed.). Academic Press, New York. pp. 339-351.

CRESS, A.E., and GERNER, E.W. (1977). "Hydroxyurea treatment affects the G1 phase in next generation CHO cells." Exp. Cell. Res. 110: 347-353.

DOJMI DI DELUPIS, G., MACRİ, A., CIVITAREALE, C., and MIGLIORE, L. (1992). "Antibiotics of zootechnical use: effects of acute high and low dose contamination on Daphnia magna Straus." Aquatic Toxicol. 22: 53-60.

FORESTI, M., GAUDIO, L., GERACI, G., and MANDUCA, P. (1986). "Inhibition of dimethylsulfoxide induced erythropoietic differentiation of murine erythroleukemia cells in culture." Cancer Res. 46: 6260-6263.

FORESTI, M., GAUDIO, L., GERACI, G., and PAOLETTI, I. (1990a). "The inhibition of erythroid differentiation in MEL cells by UV treatment. Possible defect of repair in S phase." Atti A.G.I. XXXV: 143-144.

FORESTI, M., GAUDIO, L., and GERACI, G. (1990b). 'Inhibition of MEL cells' capacity to undergo erythroid differentiation by chemicals added during induction." Mutat. Res. 234: 9-14.

FORESTI, M., GAUDIO, L., and GERACI, L. (1992). "Selective gene mutation in MEL cells." Mutat. Res. 265: 195-202.

FORESTI, M., GAUDIO, L., PAOLETTI, I., and GERACI, G. (1993). "Inhibition of erythroid differentiation in MEL cells by UV irradiation. Cell cycle and DNA repair activity." Mutat. Res. 294: 69-75.

FRIEND, C., SCHER, W., HOLLAND, J.G., and SATO, T. (1971). "Hemoglobin synthesis in murine virus-induced leukemic cells in vitro: stimulation of erythroid differentiation by dimethylsulfoxide." Proc. Natl. Acad. Sci. USA. 68: 378-382.

GOODMAN, L.S., and GILMAN, A. (eds.) (1990). The Pharmacological Basis of Therapeutics, 8th edn. Pergamon Press, New York.

MACRI, A., DOJMI DI DELUPIS. G., CIVITAREALE, C., and MIGLIORE, L. (1990). "Sensitivity of Daphnia magna Straus to four antibiotics used in animal feeding." Atti. Soc. It. Sci. Veter. XLIV: $1177-1181$.

MARTINDALE, W. (1989). The Extra Pharmacopeia, 29th edn. The Pharmaceutical Press, London. p. 1100.

MELLO-FILHO, A.C., HOFFMAN, M.E., and MENEGHINI, R. (1984). "Cell killing and DNA damage by hydrogen peroxide are mediated by intracellular iron." Biochemical J. 218: 273-275.

MIGLIORE, L., DOJMI DI DELUPIS, G., CIVITAREALE, C., and GRASSITELLI, A. (1991). "Rilevatori della tossicità degli antibiotici di uso zootecnico." Vet. Ital. XXXVII(1): 13-18.

MIGLIORE, L., DOJMI DI DELUPIS, G., CIVITAREALE, C. and GRASSITELLI, A. (1994). "Toxicity of antibiotics for agriculture to Artemia salina (L.) (Crustacea, Anostraca): alteration of population and methods of its evaluation.” Int. J. Salt Lake Res., in press.

ORKIN, S.H., HAROSI, F.I., and LEDER, P. (1975). "Differentiation in erythroleukemic cells and their somatic hybrids.” Proc. Natl. Acad. Sci. USA. 72: 98-102.

QUINLAN, G.J., and GUTTERIDGE, J.M. (1989). "Bacitracin and a Bacitracin-zinc complex damage DNA and carbohydrate in the presence of iron and copper salts." Free Radical Res. Commun. 7(1): 37-44.

QUINLAN, G.J., and GUTTERIDGE, J.M. (1991). "DNA base damage by beta-lactam, tetracycline, bacitracin and rifamycin antibacterial antibiotics." Biochem. Pharmacol. 42: 1595-1599. 